\title{
Interferon Gamma Receptor 1
}

National Cancer Institute

\section{Source}

National Cancer Institute. Interferon Gamma Receptor 1. NCI Thesaurus. Code C37286.

Interferon gamma receptor 1 (489 aa, $\sim 54 \mathrm{kDa}$ ) is encoded by the human IFNGR1 gene.

This protein plays a role in inteferon-gamma-mediated signaling. 